\title{
Metonymien i moderne lyrik
}

Hvad enten man betragter de retorisk eller de fænomenologisk orienterede litteraturteorier, har en gennemgående tendens været, at metaforen altid har været tilkendt højere status end metonymien. Den lave vurdering af metonymien har resulteret $i$, at den stadig i dag ignoreres i de fleste afhandlinger om litterært billedsprog, ${ }^{1}$ og hvad angår metonymiens rolle inden for lyrik glimrer denne stort set ved sit fravær i den eksisterende forskning. Det følgende er derfor et forsøg på to ting. For det første at give et rids af og et par voteringer i forhold til metonymiens rolle i den litterære kritik frem til i dag. Og for det andet med udgangspunkt i en række tekstlæsninger at argumentere for den tese, at metonymien ikke er den underordnede variationsfigur, som

1. I dansk sammenhæng kan man blandt de mange afhandlinger om litterært billedsprog nævne Thomas Bredsdorff: Med andre ord, Kbh. 1996; Mia Graae: Når ørknen blomstrer. Edith Södergran i lyset af tre metaforteorier, Kbh 1999; Carsten Madsen: „De fragmentariske billeder«", in Madsen: Om laesning. Kierkegaard, Kafka, Mallarmé og Jacobsen, Århus 1995; Peer E. Sørensen: Udløb i uendeligheden, Kbh. 1997; Isak Winkel Holm: Tanken i billedet. Søren Kirkegaards poetik, Kbh. 1998; Dan Ringgaard: Den poetiske lakage, Kbh. 2000; Ole M. Høystad: Bildeunivers eller bilde av universet? Per Højholts poetiske praksis, Oslo 1998; Lis Møller: „Om figurativt sprog«, in Møller (red.).: Litteraturanalyse, Odense 1995 og Atle Kittang: „Det billedmessige«, in Per Krogh Hansen og Jørgen Holmgaard (red.): Billedsprog, Kbh. 1997.

Billedsprogsdiskussionerne i disse spænder her fra dem, der har et strengt retorisk udgangspunkt - f.eks. Høystad - til dem, der vægter det fænomenologiske - f.eks. Kittang - med en klar overvægt for de retorisk orienterede studiers vedkommende. I visse af afhandlingerne forsøges traditionerne kombineret. Det gælder f.eks. hos Møller, Bredsdorff og Graae, hvor de to sidste bl.a. forsøger at kombinere Paul de Mans nyretorik med den kognitive semantik. Hvad angår teoretiske udgangspunkter i forhold til læsningen af forskellige digteres værker, leverer Sune Agger i "Billedsprog og erkendelse», in ibid.nr.1 (1999), en række interessante refleksioner over, hvorledes bestemte metaforteorier korresponderer med poetiske strategier inden for specifikke forfatterskaber. Kun en enkelt dansk artikel beskæftiger sig helt specifikt med metonymiens rolle, nemlig Jørn Erslev Andersen: „Dryssende roser - om spor i J.P. Jacobsens skrift", in Erslev Andersen: Dryssende roser. Essays om digtning og filosofi, Århus 1988. Her læses J.P. Jacobsens „Der burde have været Roser« (1882) som en tekst, der "grundlæggende set er metonymisk orienteret«, loc. cit., p. 90. Som et kuriosum, der understreger, at bestemmelsen af, hvad man skal forstå ved det metonymiske, langtfra altid er nogen enkel sag, kan det nævnes, at Lis Møller fremhæver den samme prosaskitse af J.P. Jacobsen som et eksempel på en tekst, der »er metaforisk«, loc. cit., p. 170. 
den igennem det meste af retorikkens historie har været betragtet som, men at den derimod spiller en central rolle inden for moderne lyrik.

\section{Metaforisk dominans}

I The Rule of Metaphor har Paul Ricœur opridset to forskellige typer af metaforer:

"the physical metaphor, that is, one in which two physical objects (whether animate or inanimate) are compared'; and 'the moral metaphor, in which something abstract and metaphysical, something from the moral order, is compared with something physical'«. ${ }^{2}$

Betragter vi Ricœurs distinktion i forhold til den moderne lyriks historie, er det oplagt, at to forskellige dominerende teorier om det figurative sprog kan ses i samklang med ovenstående to metafortyper.

Den sidstnævnte - kombinationen af abstrakt og konkret substantiv kan i vid udstrækning knyttes tilbage til romantikkens symbolæstetik, hvor det sproglige billede ses som et erkendelsesorgan, der åbenbarer på forhånd givne sammenhænge mellem ideer og former, der kan sanses. Centrale formuleringer er i denne sammenhæng Goethes teori om symbolet som det organiske sammenfald mellem indhold og udtryk og Coleridges bestemmelse af »imagination«-begrebet som en evne til via det poetiske billedsprog at forsone modsatrettede, uharmoniske kvaliteter: "det almene med det konkrete; ideen med billedet; det individuelle med det repræsentative«. ${ }^{3}$ I moderne æstetik videreføres en lang række analoge begrebsdannelser spændende fra Eliots forestilling om »objective correlatives ${ }^{4}$ over den jungianske psykoanalyses »arketyper« til Gaston Bachelards idé om »the essential newness of the poetic image $\iota^{5}$ - en sådan forestilling om det poetiske billede som bærer af en eller anden dybere indsigt i en metafysisk/religiøs funderet sandhed.

Inden for de poetologiske formuleringer er tendensen til at opvurdere den abstrakt-konkret-sammensatte metafor også særdeles dominerende. Hos Paul la Coul tales der om, hvordan:

2. Paul Ricœur: The Rule of Metaphor, London 1994 (org. 1975), p. $58 \mathrm{f}$.

3. S. T. Coleridge: Biographia Literaria (org. 1817). Citeret efter Carsten Madsen, loc.cit., p. 127 (se note 1).

4. T. S. Eliot: The Sacred Wood, London 1960 (org. 1920), p.100

5. Gaston Bachelard: The Poetics of Space, Boston 1994 (org.1958), p.14. 
»Digteren genopretter den tabte Inderlighed mellem Ord og Ting. Mange Midler dertil er lagt i hans Hænder, men intet mægtigere end Billedet, der gør Abstraktionen konkret. Af Tingen, du ikke kan gribe, opstår en ny Realitet, som på en Gang er Stof og Følelse i den inderligste Omfavnelse. $\ll^{6}$

I Inger Christensens essayistik tales der om »hemmelighedstilstanden, hvor indre og ydre verden befinder sig sammen, som om de aldrig havde været skilt fra hinanden", og om at "sammenkæde eller sammensmelte ord og fænomen. $\ll^{7} \mathrm{Og}$ hos Søren Ulrik Thomsen i En dans på gloser hører man om et poetisk billedsprog, der er knyttet til et metafysisk orienteret, eksistentielt projekt. Det poetiske billede er noget, der »bliver ved med at hjemsøge mig og trygle om forløsning, men som ikke kan forløses ved at blive opsuget i nogen tilgængelig diskurs«. Metaforen kan dog, fortælles det, åbenbare sig som en mediator mellem sjælelige og fysiske forhold, som når Thomsen pludselig undfanger en formulering, der kan udtrykke en uudsigelig oplevelse af f.eks. en ildebrand i Titansgade på Nørrebro: »en ildebrand, frygtelig rød / et organ krænget op i himlens klinik. $\|^{8}$

Når man taler om symbolæstetikkens videreførelse i det 20. århundredes poesi, er det naturligvis vigtigt at bemærke, at der, sideløbende med troen på, at ånd og materiale, betydning og gestalt eller ydre og indre gennemtrænger og kongruerer med hinanden, også er en skepsis til stede. Når Isak Winkel Holm - og noget tilsvarende gælder for Carsten Madsen i »De fragmentariske billeder« - påviser Kierkegaards placering i spændingsfeltet mellem en »idealistisk forsoningsæstetik og en moderne negativitetsæstetik, « ${ }^{9}$ er det naturligvis på ingen måde et forhold, der kun gælder for Kierkegaard. Betydningsoverskuddet i den sanselige form korresponderer ikke uproblematisk med et entydigt abstrakt begreb, og der opstår en sprække mellem former og begreber. Mistilliden til overensstemmelsen mellem sanselig form og begreb finder måske sit tydeligste udtryk i den stilistiske figur, som Thorkild Bjørnvig har kaldt en »dissonantisk abstraktets genitiv«. Figuren består i, at det abstrakte og det konkrete led i en genitivkonstruktion er sat sammen i et »dissociativt kradst sammenstød «. ${ }^{10}$ Eksemplerne fra lyrikhistorien er mangfoldige - spændende fra den internationale symbolismeæra med

6. Paul la Cour: »Fragmenter af en Dagbog«, her citeret efter Heretica. En antologi, redigeret af Ole Wivel, Kbh. 1962, p. 62.

7. Inger Christensen: Hemmelighedstilstanden. Essays, Kbh. 2000, p. 42.

8. Søren Ulrik Thomsen: En dans på gloser, Kbh. 1996, p. $49 f$.

9. Isak Winkel Holm op cit., p. 33 (se note 1).

10. Thorkild Bjørnvig: "Abstraktets genitiv« (org. 1972), optrykt i: Virkeligheden er til. Litterœere essays, Kbh 1973, p. 247. 
Baudelaires »det ondes blomster«(Fleurs du mal), Rilkes »skæbnens billige vinterhatte« og Yeats »hjertets hæslige marskandiserbutik«og frem til de seneste års danske digtning med Søren Ulrik Thomsens "poesiens privathospital«, Morten Søndergaards »forstandens elektriske stol« og Lars Bukdahls »inspirationens rynkede bryn«. Figuren er i Bjørnvigs fortolkning et desperat signal om, at en forsoning mellem den moderne materielle virkelighed og de åndelige værdier på ingen måde er en selvfølgelighed. Fra at den oprindelige romantiske symbolæstetik opererede med faste referencer til absolutte værdier, forstås det moderne billedsprog som en slags erkendelsesinstrument, der kan diagnosticere civilisationens krise. Og metaforen har bl.a. ud fra denne logik sin status som den moderne lyriks mestertrope.

Med hensyn til den anden type af metaforik, som Ricœur nævner, altså den hvor man finder en sammensætning af to konkrete led, er oprindelsesstedet i udpræget grad den såkaldte interaktionsteori, som den formuleres i I.A. Richards The Philosophy of Rhetoric. Richards lægger her ikke skjul på, at en central inspirationskilde for interaktionsteorien er surrealismen, hvorfor også en af Bretons formuleringer om poetisk billeddannelse står i centrum i Richards diskussion:

"At sammenligne to genstande, hvis egenskaber ligger så langt fra hinanden som muligt, eller på anden vis at sammenstille dem på en pludselig og slående måde, det forbliver den højeste opgave, som poesien kan aspirere til. $\|^{11}$

Man bemærker, hvordan der ikke længere tales om indsigt i metafysiske tilværelsesdimensioner, men om »objects«, der konfronteres med det formål at sprænge vante forestillingsrammer og skabe »striking fashion« og »disparity action. ${ }^{12}$ Metaforens aura og status er dog på ingen måde forladt, og dens erkendelsesmæssige potentiale vurderes højt. Kernepunktet i Richards metaforteori er nemlig, at to vidt forskellige betydningssfærer fusioneres eller konfronteres på en sådan måde, at der opstår en tredje, ikke-før-realiseret betydning.

Man finder mange steder i moderne digtning den surrealistiske forestilling om, at essensen af det poetiske er det Lautreamont'ske "uventede møde mellem en symaskine og en paraply på et operationsbord«. Hos Hugo Friedrich tales der om, at man i lyrikken "tvinger en irreal forening frem «, ${ }^{13}$ og hos Jørgen Sonne lyder en poetologisk refleksion med en lignende sæku-

11. I.A. Richards: The Philosophy of Rhetoric, Oxford 1936, p. $123 \mathrm{f}$.

12. Op. cit., p. 123.

13. Hugo Friedrich: Strukturen i moderne lyrik, Kbh. 1987 (org. 1956), p. 10. 
lariseret optik på digtningen som et specialiseret håndværk: »digtet skal være således beskaffent at det taler om to eller helst tre ting på én gang. $\|^{14}$

Ser man på den danske digtning, hvad angår udviklingen af en konkret forankret, toleddet metaforik, er eksemplerne talrige. Man kan her blot betragte værker inden for den ekspressionistisk-surrealistiske linie i dansk lyrisk modernisme spændende fra Johannes V. Jensens Digte 1906 og Tom Kristensens Fribytterdrømme (1920) over Rifbjergs Konfrontation (1960), Ørnsbos Digte (1960) og Sonnes Krese (1963) og frem til Carsten René Nielsens Cirkler (1999) og Tore Ornsbos Kronologi i trappeform (2001).

I alle de hidtil nævnte eksempler på diskussioner af billedsprog er én ting imidlertid karakteristisk, nemlig at der tales overordentlig meget om metaforer, men stort set ikke om metonymier.

Hos Ulla Albeck affejes metonymien kort med følgende replik: »Metonymien er stadig levende som sprogligt Fænomen, men i kunstnerisk nyskabende Funktion hører den mest den ældre Litteratur til. ${ }^{15}$ I den mest udbredte nordiske indføring i lyriklæsning, Kittang \& Aarseths Lyriske strukturer lyder beskrivelsen af metonymien: »I våre dager blir de metonymiske bildene forholdsvis sjelden brukt i lyrisk diktning, og de gangene de forekommer, eier de av og til et visst retorisk og stivt preg. « ${ }^{16}$ I Steffen Hejlskov Larsens toneangivende billedsprogsrefleksioner fra 1960'erne og 1970'erne afskibes metonymien med en bemærkning om, at »i moderne stilforskning " »opfattes metonymi og synekdoke som underafdelinger af metaforen. ${ }^{17} \mathrm{Og}$ i de seneste års mange studier af det figurative sprog inden for dansk lyrik er det en helt typisk og relevant kommentar, der kunne gælde for de fleste afhandlinger, når Poul Behrendt i en anmeldelse af Thomas Bredsdorffs Nordbrandt-bog, Med andre ord (1996) påpeger, at glosen "metonymi« kun optræder ét sted i værket. ${ }^{18}$

\section{Metonymiens genkomst}

Enkelte undtagelser er der dog fra ovennævnte negligering af metonymien i dansk litteraturkritik. Det drejer sig i første omgang om de litterater, der allerede i 1960'erne - bl.a. Hans Jørgen Schiødt i Kommunikation og litte-

14. Claus Clausen: »Jørgen Sonne«, in Claus Clausen: Digtere i Forhør, Kbh. 1966, p.111.

15. Ulla Albeck: Dansk stilistik, Kbh. 1963 (org. 1945), p. 123.

16. Atle Kittang \& Asbjørn Aarseth: Lyriske strukturer, Oslo 1998 (org. 1968), p. 95.

17. Steffen Hejlskov Larsen: »Metafor«, in Gyldendals Litteraturleksikon, Kbh. 1974, p. 151.

18. Poul Behrendt: Anmeldelse af Thomas Bredsdorff: Med andre ord, Kbh. 1996, in Weekendavisen 9. februar 1996. 
ratur (1967) og Hans-Jørgen Nielsen i eksempler (1968) - havde øje for den afhandling, der om nogen har været banebrydende for de litteraturteoretiske overvejelser over metonymien fra dette århundrede, nemlig Roman Jakobsons »To aspekter af sproget og to typer af afatisk forstyrrelse» (1956). ${ }^{19}$

Før Jakobsons afhandling finder man i vid udstrækning en reduktionistisk forståelse af metonymien som en trope, der med let gennemskuelige betydningsforskydninger - især hvad angår kausalforhold - har til formål at forhindre redundans i tekster. I den retoriske tradition fra Quintilian over Pierre Fontanier til Heinrich Lausberg og Ulla Albeck træffer man med små variationer en liste over den halve snes typer af substitutioner, som metonymien kan betegne, såsom 'årsag for virkning', 'stof for ting', 'rum for dets indhold', 'fremtrædelse for essens', 'tegn for det, som det betegner', 'egenskab for person eller ting', 'ejer for ejendom', 'kropsparter for bevidsthedstilstande forbundet med dem' samt 'tid for deres karakteristika eller produkter'. Der er i forbindelse med denne logisk opremsende præsentation af metonymi-begrebet en klar tendens til at påpege metonymiens - modsat metaforens - hyppige optræden i dagligdags sprog. Og dette har haft som konsekvens, at man har anset metonymien for at være lettere at danne og tyde, hvorfor den i forhold til metaforen er blevet anset for et mindre interessant objekt for litterær analyse.

I Roman Jakobsons strukturelle lingvistik omstødes den klassisk retoriske forståelse af metonymien som en slags mindre fin underafdeling af metaforen fuldstændigt, idet de to troper i stedet anskues i en binær opposition mellem det Jakobson betegner som henholdsvis »lighedsfigurer« og "nærhedsfigurer«. Der bliver hermed tale om en kolossal betydningsudvidelse i Jakobsons metonymi-metafor-forståelse, idet disse to 'mestertroper' i Jakobsons ræsonnement ses som fundamentale aspekter ved menneskelige aktiviteter af mange forskellige arter. ${ }^{20}$ Det gælder to former for afatiske forstyrrelser, hvor evnen til henholdvis en paradigmatisk-selektiv og en syntagmatisk-kombinatorisk orientering knyttes sammen med henholdsvis det metaforiske og det metonymiske. Det er tilfældet for freudianske psykiske forsvarsmekanismer som symboldannelse, der forbindes med det metaforiske, og forskydning, der ses i relation til det metonymiske. Det drejer sig om

19. Dansk oversættelse in $K \& K 78$ (1996). Optrykt i Per Krogh Hansen og Jørgen Holmgaard (red.): Billedsprog (se note 1).

20. Man kan i denne sammenhæng bemærke, at meningen og betydningen af begrebet metonymi ekspanderer omvendt proportionalt med antallet af såkaldte 'mestertroper'. Mens Jakobson som nævnt opererer med to sådanne, finder man som eksempler på andre moderne opvurderinger af metonymien bl.a. Kenneth Burke: A Grammar of Motives, New York $1945 \mathrm{og}$ Harold Bloom: A Map of Misreading, New York 1975, i hvilke der for begges vedkommende tales om "four master tropes«, nemlig "metaphor, metonymi, synechdoche, and irony«, jfr. Burke op.cit. p. 503. 
de billedkunstneriske stilarter surrealisme og kubisme, der anskues som baseret på henholdsvis metaforiske og metonymiske principper. Og det gælder endelig for litterære stilarter og genrer, hvor termerne poesi og romantik/symbolisme kædes sammen med det metaforiske, mens prosa og naturalisme/realisme forbindes med det metonymiske.

I forhold til Jakobsons paradigme repræsenterer Paul de Mans diskussioner af metaforen og metonymien på én gang en viderereførelse og en kontrast. Hvad angår kontinuiteten i forhold til Jakobson, holder de Man ligesom i øvrigt Jacques Lacan, der overfører begrebsparret til sin psykoanalytisk orienterede tænkning - fast ved forestillingen om den binære modsætning mellem de to troper. I direkte opposition til Jakobson er derimod de Mans altgennemtrængende nihilistiske optik. Paul de Man angriber i Allegories of Reading (1979) den klassiske vurdering af metaforen over metonymien ved at fremhæve metonymien som den sande vej til erkendelse, mens metaforen repræsenterer forblændelse og metafysisk spilfægteri. Metonymien bliver i de Mans dekonstruktivistiske ræsonnement - parallelt til allegorien - et modtræk til den falske nærværsmetafysik, som siges at klæbe til metaforen, idet metaforens høje status bl.a. er blevet begrundet med, at den repræsenterer noget autentisk, at den peger på skjulte slægtskaber eller korrespondancer mellem ting i verden, og at den giver os en højere grad af sandhed end den, det normale diskursive sprog kan formidle.

Mellemstationen i forhold til de to ovenstående positioner - altså henholdvis Jakobsons optimistisk-pragmatiske relatering af metonymi-metafordikotomien til alverdens fagområder og de Mans illusionsløse dekonstruktion af den samme binære modsætning som logocentrisk - er det måske mest tekstanalytisk skarpe bidrag til diskussionen af metonymiens rolle i litteraturvidenskaben Gérard Genettes essay »Metonymi hos Proust fra Figures III (1972).

Genette har som Stephen Ullmann i Style in the French Novel (1964) og Paul de Man i Allegories of Reading taget sit udgangspunkt hos Marcel Proust, idet denne digter eksplicit har fremlagt en række betragtninger vedrørende metaforens særlige kvaliteter sammenlignet med metonymien. ${ }^{21}$ En kerneformulering i Genettes læsning af et stykke fra På sporet efter den tabte tid (1913-27):

"Langt fra at være antagonistisk og uforenelige støtter metafor og metonymi sig til hinanden og fortolker hinanden, og at give sidstnævnte, hvad der tilkommer den, skal ikke bestå i at opstille en konkurrerende liste herover som modstykke til listen over metaforer, men snarere i at 
vise tilstedeværelsen og virkningen af deres »co-eksistens«-forhold inden for den samme analogirelation: metonymiens rolle inde $i$ metaforen. ${ }^{22}$

Genettes pointe er essentiel i forhold til stort set enhver tekstanalyse. Man kan i en mængde litterære tekster - som Genette gør det hos Proust påpege, at de digteriske billeder, som vi normalt kategoriserer som metaforer, er kontekstuelt opladede eller - som Genette udtrykker det - at der ofte ligger en "spatialt, temporalt» eller "psykologisk« motiveret nærhedsrelation til grund for »det metaforiske forestillingsarbejde $«{ }^{23}$

Skal man problematisere Genettes argument, er det oplagt, at det forholder sig enklere med det, vi kalder 'spatial og temporal nærhed', end med den diffuse størrelse, man kan kalde 'psykologisk nærhed'. Lad mig give to centrale eksempler fra dansk prosa, i forhold til hvilke Genettes argument er en lysende klar - men tekstanalytisk set absolut ikke uproblematisk øjenåbner. Det første er fra Blichers Brudstykker af en Landsbydegns Dagbog:

„Et plaisant Vejr! Solen staaer op saa rød, som en brændende Glød! det ser ret curieux ud, naar den saadan skinner igjennem de hvide Træer; og alle Træerne see ud, som de vare puddrede [..] $\ll^{24}$

Vi møder her den tolvårige Morten Vinge, der efter i dagbogens første afnit at have været latinskolelev nu er blevet kammertjener. Han har skiftet miljø til den elegante og forfinede franskinfluerede hofkultur på herregården, og Blichers genistreg er selvfølgelig, at han lader dette skift afspejle sig totalt i fortællerens sprogbrug. Morten Vinge labber herregårdskulturen ("plaisant», "curieux«), i hvis centrum den elskede Frøken Sophie optræder, i sig. Og den

21. Paul de Mans diskussion af Proust i Allegories of Reading knytter sig tæt til Genettes tekstanalyse. Men hvor Genette taler om, hvordan "metafor og metonymi« støtter "sig til hinanden og fortolker hinanden" og indgår i et " co-eksistens'-forhold", er det de Mans pointe, at der er tale om en apori mellem det, teksten postulerer (altså metaforens primat), og det, der i virkeligheden foregår i teksten (altså at det metonymiske dominerer). De Mans argumenter lægger sig tæt op ad den pointe, der går igen i det meste af hans nyretoriskdekonstruktivistiske kritik, nemlig at der forekommer diskontinuitet mellem på den ene side sprogets grammatiske og referentielle funktion og på den anden dets performative og retoriske funktion. I forhold til denne fremstillings overvejelser over metonymiens rolle i moderne lyrik er det oplagt, at de Mans argumenter kunne knyttes til alle mine tekstlæsninger, idet der aldrig i den foreliggende forskning eksplicit peges på det metonymiskes betydning i de forfatterskaber, der bliver berørt, mens der som nævnt tales usandsynligt meget om metaforer i forbindelse med moderne digtning.

22. "Metonymi hos Proust«, i dette nr. af $K \& K$, p. 10.

23. Loc. cit., p. 11.

24. St. St.Blicher: Brudstykker af en Landsbydegns Dagbog (org. 1824), in Blicher: Hosekrammeren og andre noveller, Kbh. 1955, p. 127. 
ubehjælpelige og naive unge mands totale verdensfortolkning afspejler sig raffineret i det billedsprog, han mobiliserer i sin ekstatisk opløftede tilstand, idet det figurative sprog refererer til objektet for hele hans længsel: Solen sammenlignes med »en brændende Glød« (altså kakkelovnen i herregårdstuen), og om træernes sne bruges en metafor, der om nogen udgør essensen af den franske hofkultur: "puddrede«. Der er i et og alt - helt i samklang med Genettes Proust-læsning - tale om metaforer og sammenligninger, der er kontekstuelt motiverede. Eller sagt på en anden måde: om metonymier.

Det næste eksempel er indledningen til H.C. Branners »De blaa Undulater«:

"Nils var bange for Katrine. Naar han legede paa Vejen kom hun tit hen og drillede ham, somme tider slog hun ham skønt han ingen Ting havde gjort hende. Hun kom gravalvorlig hen og smækkede en flad Haand ind i Ansigtet paa ham saa det gnistrede, bag Gnisterne stod hendes hvide trekantede Fjæs, et alvorligt Katteansigt med to store Øjne midt i. ${ }^{25}$

I passagen ser man en typisk Branner'sk personbundet synsvinkel, som er knyttet til den bløde og forsvarsløse niårige Nils, der er paralyseret og fascineret af den jævnaldrende, hårde, aggressive, forsømte og utilpassede Katrine. Med en række klassiske impressionistiske virkemidler - såsom fænomenologisk apperception (»en Haand lige i Ansigtet saa det gnistrede«), ikke-logisk ordstilling (»hun bare saa paa ham»), talesprogsfarvning (»trekantede Fjæs «) og knap parataks - mimes den stakåndede, hektiske og rykvise omverdenssansning og det nødtørftige sanseberedskab hos den chokerede dreng. Men så kommer der pludselig en metafor, der bryder totalt med den personbundne synsvinkel: »et alvorligt Katteansigt med to store Øjne midt i«, og meningen er selvfølgelig klar fra Branners side. Med et billede - der altså rækker ud over bevidsthedsuniverset hos den niårige personalfortæller fra begyndelsen af afsnittet - klargøres ved fortætning, destillation og selektion i ét enkelt billede Katrines dominerende adfærdsmønster: det stivnede, det kolde og det uberegnelige.

Spørgsmålet om en kontekstuelt opladet og motiveret metaforik, altså en metonymisk modus, er imidlertid ved Branners moderne - med Erich Auerbachs udtryk - "multipersonelle synsvinkel« straks mere kompliceret end ved Blichers jegfortæller. For godt nok er »et alvorligt Katteansigt med to store Øjne midt i«ikke metonymisk set i forhold til den spatialitet og temporalitet, som omkranser novellens vigtigste personbundne optik, altså Nils', men betragter vi derimod metaforen i relation til den overordnede forfatter-

25. H.C. Branner: »De blaa Undulater«(org. 1939), in De blaa Undulater, Kbh.1957, p. 5. 
bevidsthed i novellen, kan den i allerhøjeste grad siges - med Genettes udtryk - at have "psykologisk nærhed « i forhold til det »metaforiske forestillingsarbejde«. For netop dyr (fisk, fugle, mus, katte etc.) er i Branners tidlige forfatterskab det faste stof, som de klare pædagogiske metaforer og sammenligninger gøres af som en konsekvens af hans biologisk-evolutionistiske og kausalt-psykoanalytisk funderede livssyn. Og »Katteansigt«-billedet forbinder i fortællingen en lang række betydningselementer rundt omkring i novellen på såvel realplan (de blå undulater) som billedplan (Nils' hoved sammenlignes med »et $A g$ « etc.).

Så konklusionen er - som det også ligger i Genettes kerneformulering om, at "metafor og metonymi« støtter "sig til hinanden og fortolker hinanden« - at kategoriernes grænser er glidende, dvs. at det samme udtryk udmærket på én gang kan betragtes som en metafor og en metonymi afhængig af, hvilken optik disse betragtes udfra. Der er i de fleste prosatekster tale om et kontinuum, hvor graden af metaforisering og metonymisering varierer, men begge tendenser er oftest tilstede.

\section{Metonymisk lyrik}

Modsat prosagenren, med særlig vægt på Proust, er spørgsmålet om det metonymiske inden for moderne lyrik meget lidt berørt. Man synes i det meste lyrikteori at have stillet sig tilfreds med refleksioner med udgangspunkt i begrebet »metafor«. I sit klassiske kulturkritiske essay Menneskets fordrivelse fra kunsten lancerer Ortega y Gasset udtrykket »metaforernes højere algebra $\ll^{26}$ som et kendetegn ved moderne lyrik og billedkunst. Og man ser - helt i overensstemmelse med Jakobsons henføring af metaforen til den lyriske genre og strømningerne romantik og symbolisme - hvordan adskilllige behandlinger af moderne lyrik i deres beskrivelser af det metonymiske forholder sig ekskluderende, som når Morten Nøjgaard karakteriserer den eksperimenterende lyrik med udgangspunkt i et fokus på »dristigheden« i den "semantiske afstand mellem grundord og billedord «, ${ }^{27}$ eller når Hugo Friedrich taler om den moderne digtning billedsprog som ét, der pr. definition udelukker det metonymiske:

»Poesiens ældste midler, sammenligning og metafor, håndhæves på en ny måde, der tvinger en irreal forening frem af det tingsligt og logisk uforenelige. ${ }^{28}$

26. Ortega y Gassét: Menneskets fordrivelse fra kunsten, Kbh. 1945 (org. 1925), p. 41.

27. Nøjgaard, Morten: Litteraturens univers, Odense 1976, p. 77. 
I det følgende vil jeg derfor anstille den tese, at Jakobson, Nøjgaard, Friedrich m.fl. ganske vist har ret i, at metaforik med en høj grad af »disparity action" er udbredt i modernistisk lyrik, men at denne "dristighed" langtfra sker på bekostning af det metonymiske. Tværtimod er det metonymiske en helt central integreret del af det lyrisk-modernistiske figurative sprog. Som et eksempel på dette kan man betragte en tekst, der om nogen normalt henregnes til det, som bl.a. Hans-Jørgen Nielsen har betegnet som "metaformodernisme«, nemlig Rifbjergs »Jern« fra Konfrontation.

Digtet starter med at konstatere, at de vante begreber ikke slår til, når det gælder forsøget på at beskrive en følelse, der rører sig i det lyriske jeg:
"Uden fladt at tale om
angst, ikke engang broangst
må man nævne respekt, nervøs
beskedenhed, ironisk
forsvarspræget indstilling
til større stålkonstruktioner
broer, kraner, drejeskiver
stålbygningsstilladser og
frem for alt overdimensionerede
mudderpramme, ganske vist
et stykke på afstand omgivet
af gråduft, sumpduft og
omkranset af skovllyde
tandhjul, opdykket jernfortid
guflende i det ukendte
mareridt, henter længst
udsvedte drømme, gumlende
host af fortid, nattevåde
opløste sengetæpper og smagen
af jern i munden mens feberen
er højest, muddermaskinefølelse
af uafrysteligt konsistensfedt. i $^{29}$

En læsning af ovenstående kunne hævde, at digtet repræsenterer metaforens triumf. I digtets lange rablende associationsstrøm søger det lyriske subjekt dækning for en psykisk angstpræget tilstand, der ikke lader sig udtrykke i

28. Friedrich op. cit., p. 10 (se note 13).

29. Klaus Rifbjerg: Konfrontation, Kbh. 1960. 
nogen vanlige diskurser. $\mathrm{Og}$ automatskriften synes til sidst at falde til ro i kraft af, at den perfekte metafor eller »the objective correlative« - svarende til Thomsens en »ildebrand, frygtelig rød / et organ krænget op i himlens klinik« - åbenbarer sig: "muddermaskinefølelse / af uafrysteligt konsistensfedt.»

Der er imidlertid argumenter for, at det er forkert at betragte »Jern« som et digt, i hvilket metaforen er det centrale element. Forløbet i digtet kan anskues som en metonymisk struktureret associationskæde med en betydningsglidning fra begreber (1. 1-5) over konkrete genstande (1.6-10) til sansningen af et afgrænset rum med en arbejdende muddermaskine (1.11-14) og endelig til traumatiske angstfantasier i forbindelse med sygdom (1.17-22). Og for hver eneste af de mange elipser, som strofen består af, kan man konstatere, at relationerne mellem de sidestillede led er funderet i artsfællespræg (typer af angst og krisetilstande eller monstrøse moderne maskiner) eller spatial nærhed (havnebassinet og sengelejet). Derudover kan tekstens komplekse synæstetisk prægede poetiske billeder, der i traditionel terminologi kunne benævnes metaforer, i vid udstrækning karakteriseres som metonymier med udgangspunkt $\mathrm{i}$ den klassiske retoriks underopdeling af disse i kategorier som: 'årsag for virkning' (»skovllyde«), 'rum for dets indhold' (»sumpduft«), 'stof for tingen' (»jernfortid«) eller 'egenskab for ting' (»opløste sengetæpper«). Metaforerne i »Jern« er kort og godt opbygget af metonymier, og man kunne polemisk hævde, at 'metonymimodernisme' ville være et lige så rammende begreb i relation til et digt som ovenstående, da man næppe finder mange andre tekster, der rummer en så stor koncentration af metonymier som dette danske konfrontationsmodernistiske digt.

Man kunne i forbindelse med Rifbjergs digt argumentere for, at den metonymiske tendens kan ses i forlængelse af den tidlige 1960'er-digtnings dyrkelse af det fragmentariske og konkret sansede i en poetik, hvis udgangspunkt er et opgør med den heretiske digtnings metafysiske helhedstænkning. Og man kunne pege på, at Rifbjerg (f.eks. i Amerika-digtene fra Konfrontation) er en vigtig eksponent for bruddet med en europæisk orienteret Baudelaire-tradition med en patosladet, religiøst farvet metaforæstetik til fordel for en amerikansk Whitman-tradition med en mere sækulariseret metonymisk baseret poetik, hvorved Rifbjerg altså kan ses som en forløber for sentresserdigtere som Laugesen, Tùrell og Høeck, der dyrker den amerikanske avantgarde fra 1950'erne og 1960'erne.

Alligevel er det spørgsmålet, om modsætningen mellem sensymbolisme og konfrontationsmodernisme er så skarp, som man i diverse polemiske litteraturkritiske essays har forsøgt at få den til at se ud, idet man kan pege på, at der jo også hos digtere som la Cour, Sarvig, Bjørnvig og Gustava Brandt forekommer et stofligt orienteret billedsprog og en sanseforankret tilværel- 
sestolkning med inspiration fra imagismen og surrealismen. ${ }^{30}$ Som et argument for, at den sensymbolistiske danske tradition måske ikke placerer sig så langt fra Rifbjergs konfrontationsmodernistiske billedsprogsæstetik og altså på ingen måde er anti-metonymisk, kan man betragte sensymbolismens vigtigste repræsentant i 1980 'er-digtningen, nemlig Pia Tafdrup. En central tekst fra Når der går hul på en engel er »Sår«:

„Uden ord
glider dagen gennem kroppen
og langs væggen vokser
feberlandskabet frem
hænder bærer lugten
af sygdom med sig
og kvalme dampe af ensilage
slår ud gennem lugen
fra barndommens silobrønde
og fylder den fugtige luft
eller det varme blod fra hønen

blot et enkelt slag

mod hjørnet af skuret

blot et enkelt slag

og hønens hoved

dingler dybt fra kroppen

kun få stænk på hånden

feberhånden

karlen med den flækkende finger

altid skal han røre ved mig

altid skal han trykke mig ind til sig

før han sætter mig op på hesten. ${ }^{31}$

Tafdrups digt er som Rifbjergs konstrueret som en associationsstrøm, hvor kæden af metonymisk forbundne led bevæger sig i retning af et fortrængt barndomstraume. I glidningen fra de poetiske billeder af nutidens tilstand af

30. Peter Stein Larsen: Modernistiske outsidere, Odense 1998, p. 20 og p.197.

31. Pia Tafdrup: Når der går hul på en engel, Kbh. 1981. 
fysisk og psykisk svækkelse og ubehagelig lugt som følge af sygdom (»langs væggen vokser / feberlandskabet frem«, "hænder bærer lugten / af sygdom«) til barndommens ubehagsfølelse og traumatiske oplevelser af magtesløshed (»kvalme dampe af ensilage«, »feberhånden / karlen med den flækkende finger«) er der, som man ser, ikke skyggen af den surrealistiske metaforæstetiks "uventede møde mellem en symaskine og en paraply på et operationsbord", men klare og veldefinerede, kausalt relaterede, metonymiske forbindelser. Og i den sidste del af den traumatiske bevidsthedsstrøm er forbindelsen mellem slagtningen af hønen og det seksuelle overgreb ligeledes funderet i metonymiske nærhedsrelationer inden for "feberlandskabet«, dvs. barndommens landmiljø, hvor karlens hånd med »den flækkede finger« indgår i begge scenarier. Vi ser altså i Tafdrups digt nøjagtigt som i Rifbjergs, at tekstens få, men centrale metaforer -»feberlandskabet« og »feberhånden« - i et og alt er opbyggede af metonymier.

Vil man videre vurdere forestillingen om metaforens primat over metonymien i modernistisk lyrik, kan man med fokus på de to ovenstående digte gøre endnu en interessant iagttagelse. En række ofte citerede - af bl.a. Genette, de Man, Culler og Lis Møller - formuleringer af Proust om det særligt kvalificerede, »evigtgyldige« ved det metaforiske kan her hævdes at komme til kort. Proust anfører med hentydning til metonymien, at »man kan i en beskrivelse lade de genstande, der optrådte på det beskrevne sted, følge efter hinanden i én uendelighed «, hvorved det metonymiske altså fremstilles som en værdi- og meningsløs proces, mens han i forbindelse med det metaforiske taler om, hvordan man tager to genstande eller sanseindtryk og »lukker dem inde $\mathrm{i}$ en skøn stils kæderinge. ${ }^{32}$ Men vender vi tilbage til eksemplerne fra Rifbjerg og Tafdrup ser vi, at der på ingen måde er tale om, at associationskæderne finder hvile, dvs. at der signaleres ro hos det lyriske jeg, i det øjeblik den 'gode metafor' - såsom "feberhånden« og "muddermaskinefølelse af uafrysteligt konsistensfedt" - har manifesteret sig. Begge digte fortsætter nemlig med opremsninger, og det bliver ikke den komplekse metaforiks 'evige stil', der vinder, dvs. bliver digtets bedste og sidste svar på, hvordan det psykiske traume, som teksten kredser om, kan formuleres, men derimod den hudløse kontekstuelt bundne talesproglige formulering: „Er man underst?«(Rifbjerg) og "altid skal han trykke mig ind til sig / før han sætter mig på hesten« (Tafdrup), lyder de sidste formuleringer i de to digte. ${ }^{33}$

32. Marcel Proust: På sporet efter den tabte tid (bd.7) (1913-27), Kbh. 1994, p. 193.

33. For en grundigere læsning af de to digte samt en placering af teksterne inden for forfatterskaberne henvises der for "Jern«"s vedkommende til Finn Brandt-Pedersen: Modernisme og paedagogik, Kbh. 1966, Torben Brostrøm: Klaus Rifbjerg, Kbh. 1970 og Lis Møller: „Konfrontation", in $K \& K 40$ (1981), og for "Sår «'s vedkommende til Peter Stein Larsen: Digtets krystal, Kbh. 1997 og Finn Stein Larsen: „Stiksår og mobiler«, in Anders Østergaard (red.): Vandmarker, Kbh. 1999. 
At det metonymiske er en uadskillelig del af det metaforiske i store dele af den modernistiske lyrik, og at metaforen kan betragtes som et afledt særtilfælde af det metonymiske, som Umberto Eco i The Role of the Reader (1979) samt flere af de omtalte Proust-baserede studier foreslår, bevirker dog naturligvis ikke, at der ikke er tekster, hvor henholdsvis det metaforiske og det metonymiske er mere eller mindre fremtrædende. Et centralt eksempel på dette er Tom Kristensens »Det blomstrende Slagsmaal« (1920) og BrobyJohansens »FORAARET KOMMER TIL CAFEEN« (1922) - to digte, der måske udgør det mest prototypiske eksempel på Bloom'sk »anxiety of influence«, vi har overhovedet inden for dansk lyrik. ${ }^{34}$

Kristensens digt er et stykke klassisk lyrisk modernisme, der er konstrueret med et "realplan« - et værtshusslagsmål - og et »billedplan« - et mytisk-eksotisk »sommergrøn Ø«-eksteriør med "Guder», »Sole» og "vilde Blomster«. Det billedsproglige stof er hele vejen igennem struktureret således, at der er metaforisk korrespondance mellem elementer fra realplan og billedplan: »Et grønt Billard« er »en sommergrøn Ø«, billardkuglerne er "Sole«, spillerne er »Guder«, slaget på den ene spillers mund er en »Valmue«, slaget i øjet er»en Stedmoderblomst«etc.

Helt anderledes med Broby-Johansens digt, i hvilket digteren - samtidig med at han bruger præcis samme motiv som Kristensen - har begået det mest udprægede eksempel på overførsel af malerkunstens kubistiske æstetik til digtningen, som man finder på dansk. Man kan på denne vis også se en klar overensstemmelse med Jakobsons tese om, at det metonymiske knytter sig til kubismen, mens det metaforiske forbinder sig til surrealismen (og ekspressionismen). For betragter vi herefter det figurative sprog i »FORAARET KOMMER TIL CAFEEN«, ser vi, at det i et og alt er metonymisk eller synekdokisk struktureret. Der er ingen »disparity action« af den art, der forekommer mellem Kristensens real- og billedplan, idet de romantisk-idylliske naturbilleder, som optræder i digtet er knyttet metonymisk til digtets handling via den unge blomstersælgende pige, der træder ind i cafeen:

\author{
TRETTEN ÅRS BLOMSTERSÆLGERSKE KOMMER \\ ALLE HENDES LINIER ER ELLIPSER \\ RUMMETS TERNING BLIR ROSENRØDME \\ STILHED EVIGGRØNNER / BLÅREGNER \\ BJERG / TRA / SØ
}

34. For en grundig behandling af „FORAARET KOMMER TIL CAFEEN« og spørgsmålet om, hvorvidt Broby-Johansens digt er et "svar»på Tom Kristensens cafédigt "Det blomstrende Slagsmaal« henvises der til Finn Klysner: „Digteren Broby - mellem romantik og revolution«, in Olav Harsløf (red.): Broby - en central outsider, Kbh. 2000, p. 115. 
$\mathrm{Og}$ fokuserer man på resten af digtet, er metonymierne inden for underkategorierne årsag-for-virkning (»GASBLEG STØVLUFT«, „GULVETS MØGGRØNNE KVADRAT« og "BILLARDETS SPINATFALMEDE AF PERSPEKTIVET BRAT TILSPIDSEDE FIRKANT») og egenskab for person (»GULT OVAL-ANSIGT GRINER«, »DRUKKEN RABER«, "ZINNOBER FALDER BAGFRA OVER BUESKULDRE«) altdominerende i billedsproget.

Et interessant spørgsmål melder sig afsluttende, når vi betragter Kristensens metaforisk funderede billedsprog i forhold til Broby-Johansens metonymisk konstruerede, nemlig i hvor høj grad disse variationer, hvad angår brugen af troper, kan opfattes som betydningsbærende. Når Lis Møller opsummerer den af bl.a. Paul de Man profilerede modsætning mellem de to troper med begreberne "sandhed, essens, sammenhaeng, helhed, nødvendighed og bestandighed - versus fremtroedelse, partikularitet, tilfaldighed og tidsbundethed $\aleph^{35}$ er der naturligvis kun sagt noget om, hvordan det kan forme sig i meget generelle tilfælde. For i Kristensens tilfælde har vi jo et digt, hvis modus er så gennemsyret af ironi, at ingen ved deres fulde fem vel ville hævde, at der var tale om nærværsmetafysik og tro på helhed, mening og bestandighed i de dissonantiske korrespondancer, som det poetiske billedsprog skaber mellem fulde billardspillere og guder. Derimod er der i Broby-Johansens tekst - som flere analyser har påpeget ${ }^{36}$ - langt mere patos og efterslæb fra dansk romantik, end man kan finde noget sted hos Kristensen. Men i disse slutninger er der ikke noget nyt. I hvert fald ikke set i forhold til to af de bedste bidrag til diskussionen af det billedsprogliges betydning i digtningen af Lis Møller og Atle Kittang, hvor der gøres forsøg på at bygge bro mellem en retorisk og en fænomenologisk vinkel på det figurative sprog. Møllers klare, korte og præcise formulering af sagen lyder: „Det figurative udtryk er udspændt mellem billede og sprogspil. At analysere figurativt sprog kræver derfor en flerfoldighed af læsestrategier. ${ }^{37}$

\section{Metonymien og interaktionsteorien}

Efter at vi har konstateret, at det uden besvær lade sig gøre at betragte modernistisk poesi, som en type af digtning, der er konstrueret ud fra et metonymisk paradigme, står ét spørgsmål tilbage, som også blev rejst i

35. Lis Møller: „Om figurativt sprog«, in Møller (red.): Litteraturanalyse, Århus 1995, p. 172.

36. Der henvises foruden til Klysners ovennævnte artikel til Erik A. Nielsen: Modernismen $i$ dansk lyrik 1870-1970, Kbh. 1976 og Peter Stein Larsen: Modernistiske outsidere, Odense 1998.

37. Lis Møller, loc.cit., p. 158. 
starten af dette essay, nemlig hvorfor der ikke eksisterer nogen litteraturteori, der diskuterer moderne lyrik med udgangspunkt i metonymibegrebet. Mit svar på dette spørgsmål lyder ganske enkelt, at den vigtigste såkaldte metaforteori, der forholder sig specifikt og adækvat til modernistisk poesi, nemlig den såkaldte interaktionsteori, i lige så høj grad er en metonymiteori. Dette kan verificeres, hvis man går til New Criticisms to centrale kilder til denne teori, nemlig I.A. Richards The Philosophy of Rhetoric (1936) og Cleanth Brooks The Well Wrought Urn (1947).

I Richards' to essays om metaforer, "Metaphor" og "The Command of Metaphor fra The Philosophy of Rhetoric, er det bemærkelsesværdigt, at det aldrig defineres entydigt, hvad der tales om for sproglige størrelser, når Richards lokaliserer »disparity action«, "tension« eller »interaction« inden for et digts billedsprog. En ting er imidlertid klar, nemlig at hovedeksemplerne, som Richards bygger sin interaktionsteori på, er lyriske tekster, hvor det, som kaldes »tenor« og "vehicle«, ikke er et enkelt ord, men derimod en hel gruppe af ord, der ordner sig i metonymiske relationer. Hos Cleanth Brooks udbygges Richards interaktionsteori, og dette sker vel at mærke - modsat andre, der har forholdt sig til Richards' interaktionsidé såsom pragmatikeren Max Black ${ }^{38}$ og de kognitive lingvister Georg Lakoff \& Mark Turner ${ }^{39}$ inden for et æstetisk orienteret nærlæsningsparadigme. En nøgleformulering hos Brooks lyder:

"Alle de mere subtile følelsestilstande kræver nødvendigvis metaforer for at kunne udtrykkes, har I.A. Richards vist. Digteren må arbejde med analogier. Men metaforerne behøver ikke at ligge på samme plan eller være forbundet. Der er en konstant gliden frem og tilbage mellem planerne, nødvendige overlapninger, diskrepanser, modsigelser. ${ }^{40}$

Hvad der interesserer Brooks er begrebet »planer« samt den »gliden«, de »diskrepanser«, de »modsigelser« eller - med Richards udtryk - den »interaktion«, der kan foregår imellem disse. Og som hos Richards er det en implicit præmis i forståelsen af et figurativt sprog, hvor »metaforerne« ikke behøver "at ligge på samme plan«, at de billedsproglige komponenter organiserer sig i forskellige betydningssfærer eller "planer«, inden for hvilke de enkelte er knyttet sammen i metonymiske forbindelser.

38. Max Black: "More about Metaphor», in Andrew Ortony (ed.): Metaphor and Thought, Cambridge 1993.

39. George Lakoff \& Mark Turner: More than Cool Reason, Chicago 1989.

40. Cleanth Brooks: Poetisk struktur (eng. org. The Well Wrought Urn (1947)), Kbh.1968, p. 16. 
Følger vi Richards' og Brooks' teoridannelse om »interaktion« og »billedplaner« ind i dansk litteraturkritik, er klassikeren Steffen Hejlskov Larsens "Om billedstrukturer i dansk lyrik« (1966) en viderebearbejdning af Brooks" "plan«-koncept, hvor Hejlskov Larsen med udgangspunkt i læsning af en række danske digte - spændende fra J.P. Jacobsen over Jæger og Sarvig og frem til Benny Andersen og Borum - påviser, hvordan alle disse digteres tekster er opbyggede af bestemte "planmønstre« eller »billedstrukturer». Og igen dominerer begrebet »metafor« helt, mens det på intet tidspunkt anføres, at det metonymiske er et grundelement $\mathrm{i}$ "plan«-begrebet. At det forholder sig således, kan man sandsynliggøre ved at betragte en række tekster fra den danske lyriske modernismetradition.

Et første eksempel stammer fra en hovedaktør i det, som Hans-Jørgen Nielsen karakteriserede som "metaformodernisme«, nemlig Jess Ørnsbo. Vi kan her - med Richards, Brooks og Hejlskov Larsens udtryk - i næsten enhver tekst af denne digter fremlæse »disparity action« imellem to billedplaner, som det f.eks. kan ses af indledningen til det lange digt »Balladen om dem der blev i byen« fra Digte:

"Høfligt banker toget på svellerne

som en gæst der er ved

at komme for sent

Søndagen

i små ryk og stationer

og stadigt mere koncentrerede madpakker

forskyder sig udad

Hvilke mænd

solbrændte som stegte æbler

guder af bronze ophængt i loftet

i alt for små stropper

som pølser i en skorsten

Nu demonstreres kunsten at stå

ikke at have noget skarpt $\mathrm{i}$ lommerne

og tilsyneladende ikke at se på hinanden

Med et sidste ryk

falder flokken sammen

mod den sidste i rækken

en fedtet kogebog

der klapper $\mathbf{i} \star^{41}$

41. Jess Ørnsbo: Digte, Kbh. 1960. 
En New Criticism-inspireret vinkel på digtet, som den Richards og Brooks er ophavsmænd til, vil pege på, at der i digtet er tale om et »billedplan«, hvor "pølser«, "stegte æbler«, »koncentrerede madpakker«, »en fedtet kogebog« etc. tilsammen danner en betydningssfære omfattende madvarer, affald fra forbrug, fordøjelse og kropsafsondringer. Effekten i digtet beror på, at »realplanet«, altså beskrivelsen af de menneskelige aktiviteter i storbyen »interagerer« med dette billedplan, idet der hermed skabes noget tredje, der ikke ligger i hverken »storbymenneske-planet« eller »konsum-affalds-planet», men alene i konfrontationen mellem dem. I den dissonantiske sammenføring af tekstens betydningssfærer eller "planer« kommunikeres en oplevelse af, hvordan anonymisering, fremmedgørelse og tilintetgørelsen af de menneskelige drømme om sammenhæng, mening og identitet er et altdominerende vilkår.

Til grund for ovenstående fortolkning ligger en række af New Criticisms fortolkningsmæsssige grundpræmisser. For det første, at det enkelte poetiske billede skal ses i lyset af digtets helhedsstruktur, hvorved der forstås et samspil mellem bestemte »billedplaner«. Og for det andet, at såvel den retoriske skelnen mellem bogstaveligt og billedligt udtryk som mellem forskellige troper, såsom comparatio (»som pølser i en skorsten«), synekdoke/metonymi (»koncentrerede madpakker«) og metafor (»en fedtet kogebog / der klapper i«) er af helt underordnet betydning for forståelsen af teksten.

Hvad angår den sidste præmis, er det bemærkelsesværdigt, at det essentielle træk ved Ørnsbo-digtets figurative sprog er det metonymiske. Dette kan dels konstateres, hvis man ser på, hvorledes bestemte metonymiske kategorier optræder overalt i digtet. Det gælder f.eks. 'tid for dens karakteristiske træk' ("søndagen i små ryk«), 'attributter for personer' (»koncentrerede madpakker forskyder sig«) og 'fremtrædelse for essens' (»hvilke mænd [...] ophængte i loftet«). Men det fremgår også af den måde, hvorpå digtets »konsum-affalds-plan« er komponeret, idet det her er gennemskuelige associationer og kausale sammenhænge, der videreforgrener de ovennæunte metonymisk funderede forbindelser mellem digtets "realplan« og »billedplan«. F.eks. kan »en gæst der er ved / at komme for sent« og »en fedtet kogebog« spatialt klart forbindes i et middagsselskabsscenarie, i forhold til hvilke ingredienserne "pølser«, »stegte æbler« og »koncentrerede madpakker« også knytter sig metonymisk.

Ørnsbos digt er dog - uanset hvor ekstrem dets nihilistiske dyrkelse af det idiosynkratisk sansede og det fragmenterede er - i sit billedsprog et relativt traditionelt digt. Man betvivler aldrig, at New Criticisms dogme om billedsprogets rolle som en organiserende og enhedsskabende faktor i teksten holder stik. Og årsagen til dette er, at »realplan« og »billedplan« er overordentlig klart definerede i digtet. 
Modsat denne type digte finder man en række af tekster, der er langt vanskeligere tilgængelige for enhver hermeneutisk manøvre, nemlig digte i hvilke det er svært eller umuligt at identificere et "realplan«. Klassikeren inden for denne digttype er Rimbauds »Marine« (1871), hvor et »landplan« og et »vandplan« er filtret ind i hinanden. Og af highlights i den danske tradition kunne man nævne Sarvigs »Modne» (1943), Malinowskis »Myggesang» (1958), Strunges »Krystalskibet" (1982) og Lene Henningsens »Velsignelse» (1992). Sådanne digte betegnes ofte som visionære, fordi deres præg af at handle om mange ting på én gang giver dem et drømmeagtigt, uvirkeligt og særdeles fascinerende præg. En elegant poetisk beskrivelse af fænomenet fra den keltiske poet Medbh McGuckian lyder: „En serie bevidstheder slås i en bunke / den ene oven på den anden, uden arrangement. ${ }^{42}$

Det kan derfor synes passende at slutte denne sondering i metonymiens rolle i moderne lyrik hos en digter, der med sine digte placerer sig hinsides enhver klassisk retorisk forestilling om bogstaveligt og figurativt sprog, nemlig Simon Grotrian, idet denne digter om nogen betegner en yderposition inden for nyere dansk poesi, hvad angår et komplekst og hermetisk billedsprog. Et digt fra Magneter og ambrosia med titlen »Elskov« lyder:
"Kroppen er en kube
om de mørkehvide sætninger og bierne i overtal
en billedskrift, der parres med den vertikale summen
trækker blomster ud af øregange, danser fra min åbne mund
og blæsten føjer sirligt lagener til.«"

I digtet tales der efter Sonnes, Brooks' og Hejlskov Larsens opskrift om tre ting på én gang: Der er ét billedplan, der omhandler aktiviteten omkring en summende bikube. (»kube«, »bierne i overtal«, »summen«, »blomster«), ét der beskriver et erotisk forløb (»kroppen«, "parres«, "min åbne mund «, "lagener«), og ét der drejer sig om poetisk skabelse ("mørkehvide sætninger«, »en billedskrift«). Der er tydeligvis efter New Criticisms paradigme tale om en - med Kittang \& Aarseths udtryk - "vibrerende balanse« i »spenningsforholdet mellem likhet og ulikhet ${ }^{4}{ }^{44} \mathrm{Og}$ den »disparity action« eller »tension «, ${ }^{45}$ der forekommer i vekselvirkningen mellem tekstens betydningssfærer, bunder i, at de tre forestillingsområder - bikuben, seksualakten og skabelsesprocessen - på den ene side er vidt forskellige og indbyrdes i modstrid med hinanden,

42. Medbh McGuckian: Det sprog Fergus taler i drømme, Århus 1996, p. 4 .

43. Simon Grotrian: Magneter og ambrosia, Kbh. 1996.

44. Kittang \& Aarseth, op.cit., p. 79 (se note 16).

45. Richards, op.cit., p. 125 (se note 11). 
og på den anden side har visse fænomenologiske fællestræk, idet det i alle tilfældene drejer sig om hektiske, voldsomme og intensive aktiviteter.

Men ellers må man sige, at digtets fascinationskraft ligger i, at det er hermeneutisk utilgængeligt, samtidig med at det besidder en uomtvistelig skønhed eller med Bachelards udtryk »imaginær strålekrans «, ${ }^{46}$ som et resultat af at billedsproget virker strukturerende og enhedsskabende. Og her kommer så spørgsmålet om, hvorledes dette kan forklares, og svaret er så vidt jeg kan se, at Grotrians digts centrale poetiske greb er dets metonymiske organisationsprincip.

Det metonymiske kan i »Elskov« påpeges på tre forskellige niveauer. For det første kan vi - som i tilfældet med Ørnsbos digt og andre "planstrukturerede« tekster - registrere, at de enkelte billeder i digtet skabes via spatiale forskydninger, dvs. metonymier inden for hver af de tre »billedplaner«. For det andet kan vi - parallelt til digtene af Rifbjerg, Tafdrup, Broby-Johansen, Ørnsbo og et utal af andre digte - forklare det tilsyneladende hermetiske eller med Friedrichs udtryk "sansemæssigt irreale «" billedsprog med udgangspunkt i, at der forekommer en række klassisk metonymiske operationer i relation til kategorierne 'form for essens' (»kroppen er en kube«), 'stof for ting' (»mørkehvide sætninger«), ‘årsag for virkning' (»vertikale summen«) og 'egenskab for ting' (»billedskrift«). Og endelig behøver vi ikke at læse digtet med afsæt i de modernistisk-nykritiske begreber »interaktion«, »disparity action«, »dissonans« og "planstruktur« og med fokus på, at digtets komplekse »visionære metaforer« skal pege på det uudsigelige, den 'tragiske abstraktion ${ }^{94}$ eller den »tomme transcendens «. ${ }^{49}$ Tværtimod kan alle digtets betydningselementer også læses inden for ét spatialt-metonymisk paradigme. Motivet - den forrådnede insektomsværmede krop som objekt for kultiske handlinger - kendes således fra mange primitive folkeslag, og man kan da heller ikke udelukke, at der i »Elskov« ligger en allusion til den parallelt beskrevne scene fra William Goldings Lord of the Flies (1968).

Med disse punktlæsninger i dansk lyrisk modernisme - spændende fra Tom Kristensen og Broby-Johansen over Rifbjerg og Ørnsbo og til Tafdrup og Grotrian - skulle vi være ved vejs ende, hvad angår den konklusion, som jeg har forsøgt at underbygge. Denne lyder i sin korthed, at det er en fejlagtig forestilling, at metonymien - som det hævdes i de mange bidrag til diskussionen af det billedsproglige fra Ulla Albeck, Hejlskov Larsen og Kittang \& Aarseth til de seneste års talrige afhandlinger - hovedsageligt optræder i ældre litteratur, mens den i nyere digtning har udspillet sin rolle. Tværtimod

46. Citeret efter Isak Winkel Holm op. cit., p. 56 (se note 1).

47. Friedrich, op.cit., p. 52 (se note 13).

48. R.N. Maier: Paradies der Weltlosigkeit, Stuttgart 1964.

49. Friedrich, op.cit., p. 87. 
kan det metonymiske ses som et helt essentielt træk ved moderne lyrik, og en læsestrategi, der har dette in mente, vil uden tvivl kunne virke i retning af en mere nuanceret forståelse af det poetiske billedsprog og dermed af digtningen som helhed. 